удк 334.012.64:004

JEL classification: M11, M12, M15

\section{Людмила ДОлГОВА}

кандидат економічних наук, доцент доцент,

кафедра економіки та бізнес технологій, Національний авіаційний університет, Україна

E-mail: L.dolgova@meta.ua

https://orcid.org/0000-0001-9917-7065

http://www.researcherid.com/rid/K-5403-2018

\section{Галина ЯМНЕНКО}

кандидат економічних наук, доцент, доцент,

кафедра бізнес-економіки та

підприємничтва,

ДВНЗ “Київський національний економічний

університет імені Вадима Гетьмана",

Україна

E-mail: yamnenko@kneu.edu.ua

https://orcid.org/0000-0001-9927-3970

http://www.researcherid.com/rid/K-6535-2018

(С Людмила Долгова, Галина Ямненко, 2021

Отримано: 04.05.2021 р.

Прорецензовано: 18.05.2021 p.

Рекомендовано до друку: 26.05.2021 р.

Опубліковано: 26.05.2021 р.

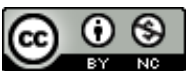

Ця стаття розповсюджується на умовах ліцензії Creative Commons AttributionNonCommercial 4. 0, яка дозволяє необмежене повторне використання, розповсюдження та відтворення на будь-якому носії, за умови правильного цитування оригінальної роботи.
Людмила Долгова (Україна) Галина Ямненко (Україна)

\section{ВИКОРИСТАННЯ IHСТРУМЕНТАРІЮ ІНФОРМАЦІЙНИХ СИСТЕМ ДЛЯ АВТОМАТИЗАЦІї БІЗНЕС-ПРОЦЕСІВ ПІДПРИЕМСТВА}

АнОтАЦІя

Вступ. Інформаційні системи відіграють важливу роль у підвищенні ефективності діяльності підприємств та ланцюгів поставок, що пов'язується з їх стійкістю. Інформаційні системи наголошують на "інтеграції інформаційних технологічних рішень та бізнес-процесів для задоволення інформаційних потреб підприємств. Інформаційні системи складаються не лише 3 поєднання інформаційно-комунікаційних технологій, а й із способу взаємодії людей із цими технологіями для підтримки бізнес-процесів. У цьому сенсі добре функціонуючі інформаційні системи - це особливі типи робочих систем, в яких люди або машини виконують процеси та діяльність, що використовує ресурси для виробництва конкретних продуктів чи послуг для споживачів. Інформаційні системи для управління діяльністю підприємств це піраміда систем, що охоплюють системи обробки транзакцій внизу до систем управління, систем підтримки прийняття рішень та виконавчі системи у верхній частині, та підтримують прийняття рішень у кожній частині ланцюга поставок.

Мета. Дослідження особливостей використання інструментарію інформаційних систем для автоматизації бізнес-процесів підприємства, виділення переваг та недоліків їх застосування.

Методика. При проведенні дослідження, зважаючи на мету та поставлені завдання, застосовувались загальнонаукові та специфічні методи дослідження. Серед них: метод наукової абстракції - при систематизації теоретичних основ застосування інформаційних систем на підприємствах, метод системно-структурного аналізу - при визначенні особливостей інформаційних систем, що використовуються для автоматизації бізнеспроцесів; метод логічного узагальнення - при дослідженні проблем застосування інформаційних систем на підприємствах; метод аналізу і синтезу.

Результати. Досліджено важливість застосування інформаційних технологій при автоматизації бізнес-процесів підприємства. Подано визначення інформаційних технологій. Визначено перелік переваг використання інформаційних технологій в управлінні підприємством. Наведено приклади програм, що використовуються у сфері взаємовідносинами з партнерами.

Практична значимість. Завдяки зростаючій увазі до стабільного розвитку підприємств, це дослідження має на меті зрозуміти роль, яку інформаційні системи відіграють в автоматизації бізнес-процесів. Важливим $€$ потенціал інформаційних систем для підвищення можливостей прийняття управлінських рішень та підвищення продуктивності праці шляхом впровадження систем корпоративних ресурсів.

Долгова Л., Ямненко Г. Використання інструментарію інформаційних систем для автоматизації бізнес-процесів підприємства. Економічний аналіз. 2021. Том 31. № 2. С. 90-97.

DOI: https://doi.org/10.35774/econa2021.02.090

Ключові слова: інформація; технології; управління; підприємство; бізнеспроцеси. 


\section{UDC 334.012.64:004}

JEL classification: M11, M12, M15

\section{Lyudmila DOLGOVA}

PhD in Economics,

Associated Professor,

Department of Economics and Business

Technologies,

National Aviation University, Ukraine

E-mail: L.dolgova@meta.ua

https://orcid.org/0000-0001-9917-7065

http://www.researcherid.com/rid/K-5403-2018

\section{Halyna YAMNENKO}

PhD in Economics,

Associated Professor

Department of Business Economics and

Entrepreneurship,

SHEI «Kyiv National Economic University named

after Vadym Hetman", Ukraine

E-mail: yamnenko@kneu.edu.ua

https://orcid.org/0000-0001-9927-3970

http://www.researcherid.com/rid/K-6535-2018

(C) Lyudmila Dolgova, Halyna Yamnenko, 2021

Received: 04.05.2021

Revised: 18.05.2021

Accepted: 26.05.2021

Online publication date: 26.05 .2021

This is an Open Access article, distributed under the terms of the Creative Commons AttributionNonCommercial 4. 0 license, which permits unrestricted re-use, distribution, and reproduction in any medium, provided the original work is properly cited.
Lyudmila Dolgova (Ukraine)

Halyna Yamnenko (Ukraine)

\section{USE OF INFORMATION SYSTEM TOOLS FOR AUTOMATION OF BUSINESS PROCESSES OF THE ENTERPRISE}

\section{ABSTRACT}

Introduction. Information systems play an important role in increasing the efficiency of enterprises and supply chains, which is associated with their stability. Information systems are focused on "integration of information technology solutions and business processes to satisfy the information needs of enterprises. Information systems are not only formed by the combination of information and communication technologies, but also the way people interact with these technologies to support business processes. In this sense, wellfunctioning information systems are particular types of working systems in which people or machines perform processes and activities that use resources to produce specific products or services for consumers. Information systems for business operations management are a pyramid of systems that integrate transaction processing systems at the bottom to management systems, decision support systems, and executive systems at the top, and support decision making at each part of the supply chain.

Purpose. To study the features of the use of information systems tools for automation of business processes of the enterprise, highlighting the advantages and disadvantages of their application.

Method. During the research, taking into account the purpose and objectives, general scientific and specific research methods were used. Among them: the method of scientific abstraction - in the systematization of the theoretical foundations of the use of information systems in enterprises, the method of system-structural analysis - in determining the features of information systems used to automate business processes; method of logical generalization - in the study of problems of application of information systems in enterprises; method of analysis and synthesis.

Results. The importance of application of information technologies at automation of business processes of the enterprise is investigated in the article. The definition of information technologies is given. The list of advantages of use of information technologies in enterprise management is defined. Examples of programs used in the field of relationships with partners are given.

Practical relevance. Due to the growing attention to the stable development of enterprises, the study aims to understand the role that information systems play in the automation of business processes. The potential of information systems for increasing the capacity to make management decisions and increasing productivity through the implementation of systems of corporate resources is important.

Dolgova, L. and Yamnenko, H. (2021). Use of information system tools for automation of business processes of the enterprise. Economic analysis, 31 (2), 90-97.

DOI: https://doi.org/10.35774/econa2021.02.090

Keywords: information; technology; management; enterprise; business processes. 


\section{Вступ}

Інформаційні системи відіграють важливу роль у підвищенні ефективності діяльності підприємств та ланцюгів поставок, що пов'язується з їх стійкістю. Інформаційні системи наголошують на “інтеграції інформаційних технологічних рішень та бізнеспроцесів для задоволення інформаційних потреб підприємств. Інформаційні системи складаються не лише з поєднання інформаційно-комунікаційних технологій, а й із способу взаємодії людей із цими технологіями для підтримки бізнес-процесів. У цьому сенсі добре функціонуючі інформаційні системи - це особливі типи робочих систем, в яких люди або машини виконують процеси та діяльність, що використовує ресурси для виробництва конкретних продуктів чи послуг для споживачів. Інформаційні системи для управління діяльністю підприємств - це піраміда систем, що охоплюють системи обробки транзакцій внизу до систем управління, систем підтримки прийняття рішень та виконавчі системи у верхній частині, та підтримують прийняття рішень у кожній частині ланцюга поставок.

Проблеми розвитку та застосування інформаційних технологій досліджувала значна кількість вітчизняних вчених. Так, Бахарєва Я. В. [1] аналізує напрями розвитку і впровадження нових облікових інформаційних систем у практику функціонування вітчизняного бізнесу, які $\epsilon$ актуальними при забезпеченні автоматизації управління їх діяльністю. У дослідженні Лагути В. В. [2] проаналізовано принцип організації системи безпеки з використанням моделі OSI та надано рекомендації стандарту кібербезпеки ISO 27000. Галаховим Є. М. [3] запропоновано модель визначення рекомендованої частоти для процесу управління кібер-ризиками на підприємстві, визначено основні принципи, ключові питання, підходи щодо ефективної реалізації даної моделі в сучасних умовах діяльності підприємства. Медушевський С. [4] розглядає питання побудови та вдосконалення системи управління якістю на основі наявних технологій для автоматизованих виробництв. Визначено структуру комп'ютерної Суя і механізми ії інформаційного забезпечення. Прищепа Є. А. [5] досліджує метод розрахунку часу транзакції в територіально розподіленій мережі великого сучасного підприємства. У дослідженнях доведено, що інформаційні системи є потужними інструментами для автоматизації бізнес-процесів підприємств.

Взаємодія між інформаційними системами та бізнес-процесами підприємства $€$ дуже складною та піддається впливу значної кількості факторів, що включають структуру організації, стандартну техніку експлуатації, політику, навколишнє середовище, управління. Розвиток інформаційних систем та їх застосування для автоматизації бізнес-процесів зумовлені необхідністю у деталізованій різноплановій інформації. Саме тому проблема використання інформаційних систем $€$ досить актуальною і потребує подальших глибоких теоретичних досліджень.

\section{Мета та завдання дослідження}

Метою даної роботи $\epsilon$ дослідження особливостей використання інструментарію інформаційних систем для автоматизації бізнеспроцесів підприємства, виділення переваг та недоліків їх застосування.

Під час проведення дослідження, зважаючи на мету та поставлені завдання, застосовувались загальнонаукові та специфічні методи дослідження. Серед них: метод наукової абстракції - при систематизації теоретичних основ застосування інформаційних систем на підприємствах, метод системно-структурного аналізу - при визначенні особливостей інформаційних систем, що використовуються для автоматизації бізнеспроцесів; метод логічного узагальнення - при дослідженні проблем застосування інформаційних систем на підприємствах; метод аналізу і синтезу. Вірогідність і обґрунтованість одержаних результатів обумовлено використанням загальнонаукових і спеціальних методів.

\section{Виклад основного матеріалу дослідження}

у широкому сенсі інформаційна система $€$ сукупністю технічного, програмного та організаційного забезпечення, а також персоналу, призначена для того, щоб своєчасно забезпечувати належних людей необхідною інформацією. Традиційні інформаційні системи спочатку були функціональною основою для безлічі організацій або функціональних сфер, але не могли об'єднувати їх в разі географічного розподілу. Одну й ту ж інформацію збирали багато разів і в багатьох місцях, і вона була недоступна в реальному часі. Робочі місця й процеси були вузько спеціалізовані відповідно до поділу праці. В результаті деяка інформація ніколи не виходила за межі окремих підрозділів корпорацій. Визначення процесів і робіт було направлено на те, щоб інформація задовольняла локальні вимоги. Коли ж інформація ставала «глобальною», інформаційні звіти про одні й ті ж події часто були різними. Таким чином, у наявності була інформаційна асиметрія між різними локальними і функціональними групами i топ-менеджментом.

Інформаційні ресурси в управлінні підприємством мають першочергове значення як обов'язкова передумова успішного виробничого процесу. 3 точки зору управлінських рішень інформаційна система розглядається як 
спеціальний інструмент у руках посадових осіб, що реалізують переробку інформації в процесі професійної діяльності. Наявність цього інструменту фактично визначає нову технологію здійснення діяльності менеджерів як фахівців управління, виводить розроблені та прийняті ними рішення на якісно новий рівень. Інформаційна система - це інформаційний контур разом із засобами збору, передачі, обробки та зберігання інформації, а також персоналом, що здійснює ці дії 3 інформацією [6, с. 55]. Місія інформаційних систем - виробництво потрібної для організації інформації для забезпечення ефективного управління всіма ії ресурсами, створення інформаційного та технологічного середовища для здійснення управління організацією.

Сучасні інформаційні системи мають на меті не просто збільшення ефективності опрацювання даних і допомогу керівнику, а й створення високоефективного виробництва. Ефективна інформаційна система значно спрощує процес управління підприємством, дозволяє вчасно зібрати, впорядкувати, обробити необхідну інформацію та прийняти вірне рішення. Структура інформаційної системи підприємства повинна містити бази даних, довідкові системи та інші сучасні засоби швидкого обміну інформацією такі, як інтернет-технології та апаратно-програмні засоби, а також бажано створити плоску структуру організації з мінімальними рівнями ієрархії для скорочення часу прийняття рішень і мінімізації спотворень у процесі розробки управлінського рішення.
Інформаційна система складається, формується і функціонує в регламенті, певних методах і структурі управлінської діяльності, прийнятої на конкретному економічному об'єкті, реалізує цілі і завдання, що стоять перед ним. Ефективність комплексної автоматизації управлінських структур в основному залежить від ступеня охоплення всіх сфер корпоративного управління. Багато в чому саме через це в останні роки стала настільки популярною тенденція побудови і впровадження комплексних корпоративних інформаційних систем.

Розвиток ринку породив потребу в широко функціональних інтегрованих корпоративних інформаційних системах, в яких поєднуються і бази для зберігання даних, і аналітичні інструменти, і системи документообігу. Однак, неможливо дати загальне визначення корпоративної інформаційної системі як набору функціональних ознак, виходячи з будь-яких загальних вимог, стандартів. Дати таке визначення корпоративної інформаційної системі можна тільки стосовно до конкретної компанії, яка використовує або має намір будувати корпоративну інформаційну систему. Корпоративні інформаційні системи - це інтегровані системи управління територіально розподіленою корпорацією, засновані на поглибленому аналізі даних, широкому використанні систем інформаційної підтримки прийняття рішень, електронного документообігу й діловодстві. Корпоративні інформаційні системи покликані об'єднати стратегію управління підприємством і передові інформаційні технології.

Типові приклади корпоративних інформаційних системах представлені в таблиці 1.

Таблиця 1. Приклади корпоративних інформаційних систем [7, с. 59]

\begin{tabular}{|c|c|l|}
\hline № & Абревіатура & \multicolumn{1}{|c|}{ Пояснення } \\
\hline 1 & СRM & Система управління взаємовідносинами з клієнтами \\
\hline 2 & EAM & Система управління основними фондами підприємства \\
\hline 3 & EIS & Інформаційна система для керівників \\
\hline 4 & ERP & Система планування ресурсів підприємства \\
\hline 5 & MES & Система оперативного (цехового) управління виробництвом \\
\hline 6 & WMS & Система управління складами \\
\hline 7 & SCM & Система управління ланцюгами поставок \\
\hline 8 & HRM & Система управління персоналом \\
\hline
\end{tabular}

Підходів до класифікації корпоративної інформаційної системи досить багато і це обумовлено великою кількістю представлених на світовому ринку рішень для бізнесу. Найчастіше використовуються наступні класифікаційні схеми:

- галузева класифікація (для торгівлі, для промисловості, для транспорту і т.ін.);

- функціональна класифікація (управлінські, облікові, бухгалтерсько- фінансові, аналітичні і т.ін.);
- $\quad$ за масштабами бізнесу, обороту компанії (дуже великий - понад 1 млрд дол., великий - 0,5 - 1 млрд дол., середній - 50 - 500 млн дол., малий - до 50 млн дол.).

Найчастіше використовується узагальнена класифікація універсальних корпоративних інформаційних систем за типом і характеристикою підприємства (табл. 2). 
Таблиця 2. Класифікація корпоративних інформаційних систем за типом і характеристикою підприємства $[8$, c. 213]

\begin{tabular}{|c|c|c|c|}
\hline № & Тип підприємства & Тип інформаційної системи & $\begin{array}{l}\text { Можливості інформаційної } \\
\text { системи }\end{array}$ \\
\hline 1 & мале & $\begin{array}{l}\text { локальні або слабо інтегровані системи з } \\
\text { домінуючою облікової функціональністю }\end{array}$ & $\begin{array}{l}\text { до 5-10 робочих місць, прості } \\
\text { бізнес-процеси }\end{array}$ \\
\hline 2 & $\begin{array}{l}\text { середнє без } \\
\text { виробництва (торгівля, } \\
\text { послуги та ін.) }\end{array}$ & $\begin{array}{l}\text { середньо інтегровані системи без } \\
\text { виробничого контуру і з СRM- } \\
\text { функціональністю }\end{array}$ & $\begin{array}{l}\text { до } 50 \text { робочих місць, оборот } \\
\text { понад } 50 \text { млн дол., більше } \\
100 \text { співробітників }\end{array}$ \\
\hline 3 & велике промислове & $\begin{array}{l}\text { повнофункціональне ERP - рішення з } \\
\text { розвиненим виробничим контуром (MES) }\end{array}$ & $\begin{array}{l}\text { понад } 100 \text { робочих місць, } \\
\text { типові бізнес- процеси }\end{array}$ \\
\hline 4 & $\begin{array}{l}\text { дуже велике (холдинг, } \\
\text { корпорація) }\end{array}$ & $\begin{array}{l}\text { інтегровані ERP - SCM - WMS - CRM } \\
\text { рішення. }\end{array}$ & $\begin{array}{l}\text { понад } 300 \text { робочих місць в } \\
\text { мережі, складні бізнес- } \\
\text { процеси }\end{array}$ \\
\hline
\end{tabular}

Найпоширенішою

корпоративною інформаційною системою в розвинених країнах 3 ринковою економікою $€$ система планування ресурсів підприємства (Enterprise Resource Planning System), створена для обробки ділових операцій організації та для сприяння комплексному та оперативному (в режимі реального часу) плануванню, виробництву та наданні послуг клієнтам. Зокрема, ERP-системи мають такі характеристики [9, с. 62]:

- готове програмне забезпечення, розроблене для середовища клієнт-сервер, як традиційної, так і такої, що базується на інтернеттехнологіях;

- можливість інтегрувати більшість бізнеспроцесів;

- обробка більшості з усіх ділових операцій організації;

- використання бази даних всього підприємства;

- забезпечення доступу до будь-яких даних організації в режимі реального часу;

- можливість інтегрувати обробку ділових операцій і дій з планування.

ERP рівень - це стратегічний контур управління. Він звільняється в цьому випадку від оперативних завдань виробництва і забезпечує підтримку бізнес-процесів підприємства в цілому. Потік інформації від виробничого блоку стає мінімальним і включає в себе сукупну керуючу і звітну інформацію по стандартам ERP з типовим часом контролю: тиждень, декада, місяць, квартал, а також «аварійні» сигнали, що вимагають негайного втручання вищого менеджменту підприємства.

Історично корпоративні інформаційні системи народжувалися в різних предметних областях i, відповідно, будувалися на різній методологічній основі: обліково-фінансовій, виробничо- управлінській, транспортно- дистриб'юторській і торговій $[10$, с. 19]. Це, з одного боку, зумовило різноманітність програмних продуктів, а з іншого породило проблему вибору через наявність у корпоративних інформаційних системах одного виробника як сильних, так і слабких у функціональному відношенні рішень. На сьогодні ринок інтегрованих рішень залишається досить представницьким.

Однак в силу триваючої уніфікації бізнеспроцесів і зростаючої затребуваності споживачами якісного інтегрованого програмного забезпечення, він постійно звужується. Відбувається це шляхом інтеграції рішень у результаті злиття компаній і придбань провідними виробниками корпоративних інформаційних системах кращих у своєму класі систем. У цілому для сучасних тиражованих корпоративних інформаційних систем характерний високий ступінь інтегрованості, наявність досить широкого набору типових бізнес-моделей, а також орієнтованість на управління ланцюгами поставок i електронний бізнес.

Будь-яке підприємство за рахунок впровадження інформаційної системи намагається реалізувати виконання найбільш актуальних завдань, що стоять перед ним за заданий проміжок часу i з залученням ресурсів, доступність яких прорахована заздалегідь за допомогою інформаційних систем. На жаль, сьогодні спостерігається скорочення обсягів фінансування на автоматизацію підприємств. Тому коштів на розробку, розвиток і підтримку «замовних» систем може і не вистачити. В таких умовах з великою часткою ймовірності, підприємство має вибір інформаційних систем з числа вже наявних. Ринок інформаційних систем постійно поповнюється новими інформаційними системами. При цьому 
велика частина інформації про них (80-90\% інформації про стан ринку інформаційних систем) може бути отримана шляхом аналізу відкритих джерел інформації. Аналіз відомостей про інформаційні системи «безпосередньо», тобто на основі інформації, розташованої на сайтах фірмвиробників, блогів, форумів фахівців і користувачів може зайняти багато часу. Набагато зручнішим було б використання вже розроблених переліків інформаційних систем, які можуть бути розглянуті в рамках проекту по автоматизації підприємства. Переліки інформаційних систем (за областями застосування) можна знайти на спеціальних сайтах (або Інтернет-ресурсах). На таких сайтах (Інтернетресурсах) користувачі IC та експерти можуть виставляти оцінки за кожним з параметрів IC, що відносяться до певної сфери діяльності.

Придбання готової, тиражованої корпоративної інформаційної системи є одним із способів її формування. Альтернативними способами $\in[11$, c. 144]:

Таблиця 3. Основні позитивні і негативні сторони способів формування корпоративних інформаційних систем [розроблено авторами]

\begin{tabular}{|c|c|c|c|}
\hline № & Спосіб & Переваги & Недоліки \\
\hline 1 & $\begin{array}{l}\text { Готові рішення ERP } \\
\text { / CSRP класу }\end{array}$ & $\begin{array}{l}\text { Основний спосіб комплексної } \\
\text { автоматизації управління бізнесом. } \\
\text { Цілісність рішення. Готові бізнес- } \\
\text { процеси, узагальнюючі кращий світовий } \\
\text { досвід. Управління в режимі реального } \\
\text { часу. Засоби розробки та інтеграції з } \\
\text { програмним забезпеченням інших фірм. } \\
\text { Організаційна стандартизація }\end{array}$ & $\begin{array}{l}\text { Висока вартість і тривалість застосування. } \\
\text { Високі впроваджувальні ризики. } \\
\text { Чутливість до організації впровадження. } \\
\text { Необхідність реінжинірингу бізнес- } \\
\text { процесів. Труднощі в оцінці ефективності } \\
\text { до введення в експлуатацію }\end{array}$ \\
\hline 2 & Рекомендовані КІС & $\begin{array}{l}\text { Повне задоволення вимог замовника до } \\
\text { функціональності, } \\
\text { масштабованості, } \\
\text { продуктивності. }\end{array}$ & 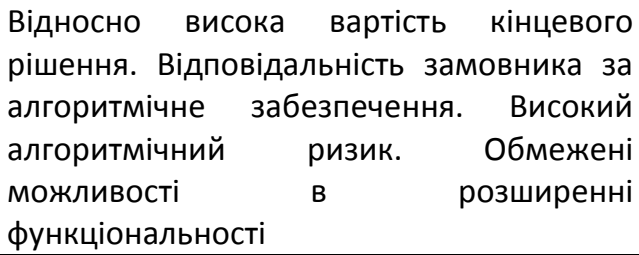 \\
\hline 3 & $\begin{array}{l}\text { Аутсорсинг, ASP- } \\
\text { технологій }\end{array}$ & 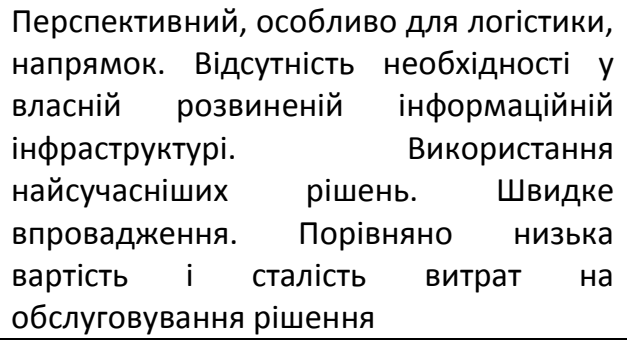 & $\begin{array}{l}\text { Необхідність високошвидкісного каналу } \\
\text { зв'язку з провайдером. Високі вимоги до } \\
\text { довірливості } \text { відносин клієнта } \\
\text { провайдером } \\
\text { функціональність рішення. Складність } \\
\text { адаптації IC до бізнес-процесів компанії. } \\
\text { Не виключені проблеми, пов'язані } \\
\text { інформаційною безпекою } \\
\end{array}$ \\
\hline 4 & $\begin{array}{l}\text { КІC швидкого } \\
\text { впровадження }\end{array}$ & $\begin{array}{l}\text { Низька вартість і невеликі терміни } \\
\text { впровадження. } \\
\text { обслуговування і навчання персоналу. }\end{array}$ & $\begin{array}{l}\text { Обмежена функціональність. Наперед } \\
\text { настроєне, типізоване рішення. } \\
\text { Відсутність інструментальних засобів. }\end{array}$ \\
\hline 5 & Модульні КІС & $\begin{array}{l}\text { Можливість гнучкого налаштування і } \\
\text { поступового, за потребою розширення } \\
\text { функціональності. Використання кращих } \\
\text { в своєму класі рішень }\end{array}$ & $\begin{array}{l}\text { Новий, маловивчений i погано } \\
\text { апробований напрямок. Особливі вимоги } \\
\text { до платформ і застосовуваних технологій } \\
\text { в базовому програмному забезпечення }\end{array}$ \\
\hline
\end{tabular}

- розробка корпоративної інформаційної системи сторонніми компаніями під бізнеспроцеси замовника (замовна, унікальна);

- оренда аутсорсинг) корпоративної інформаційної системи інтегрованого, корпоративного класу (технологія ASPApplication Service Providing);

- придбання готових інтегрованих рішень «швидкого впровадження»;

- послідовна збірка корпоративної інформаційної системи необхідної функціональності 3 модулів тиражованих систем нового покоління і сумісних модулів сторонніх розробників (на основі технології XML або на платформі розробника базової корпоративної інформаційної системи).

Кожен $з$ перерахованих способів має свої позитивні і негативні сторони і реалізується на практиці, які відображені в таблиці 3. 
У сучасних умовах питання про вибір корпоративної інформаційної системи часто $\epsilon$ ключовим стратегічним рішенням, багато в чому визначає ефективність діяльності компанії, в тому числі в галузі логістики.

Використання готових тиражованих інформаційних систем корпоративного класу $\epsilon$ основним способом комплексної автоматизації управління у виробничо-логістичних компаніях. В основі цих рішень лежить концепція комп'ютерного планування, що забезпечує отримання збалансованого за ресурсами підприємства (матеріальних, виробничих, фінансових) обсягу календарного плану графіка випуску продукції.

\section{Висновки та перспективи подальших досліджень}

Отже, у роботі досліджено потенціал інформаційних систем для підвищення можливостей прийняття управлінських рішень та підвищення продуктивності праці шляхом впровадження систем корпоративних ресурсів, систем підтримки співпраці в ланцюгах поставок та соціальних довідкових систем для підтримки стійких продажів у соціальній торгівлі. Хоча інформаційні системи відіграють важливу роль у сприянні стійкій конкурентній перевазі підприємства, все ще існує багато проблем при впровадженні інформаційної системи. Підприємства впроваджують цифрову трансформацію (тобто інформаційні системи) для того, щоб вони могли підтримувати стійкі конкурентні переваги перед іншими. Як джерело стійких конкурентних переваг, інформаційні системи допомогають поліпшити результати діяльності підприємств шляхом підвищення ефективності та результативності. Інформаційна система може бути способом досягнення стійких конкурентних переваг, використовуючи унікальні атрибути підприємства.

Роль інформаційних систем у сталому розвитку підприємств $€$ важливим питанням, яке потребує подальшого вивчення.

\section{СПИСОК ВИКОРИСТАНИХ ДЖЕРЕЛ}

1. Бахарєва Я. В. Напрями розвитку інформаційних систем і технологій обліку підприємств малого та середнього бізнесу в Україні. URL: http://nbuv.gov.ua/UJRN/efek_201 8_11_90.

2. Лагута В. В. Підвищення якості кібернетичної безпеки в інформаційно-телекомунікаційній системі підприємства. Сучасний захист інформації. 2020. № 1. C. 37-41.

3. Галахов $€$. М. Стратегічн пріоритети системи інформаційної безпеки підприємства, що залучає фріланс-ресурс. Сучасний захист інформації. 2019. № 3. С. 30-35.

4. Медушевський С. Автоматизовані інформаційні системи як елементи системи управління якістю фармацевтичного підприємства. Технічні науки та технології. 2020. № 4. С. 65-71.
5. Прищепа Є. А. Метод розрахунку часу транзакцій у розподілених комп'ютерних мережах при побудові інформаційних систем підприємств. Вісник університету "Україна". 2016. № 1. С. 175-180.

6. Павлик В. П. Систематизація методів у інформаційному забезпеченні управління підприємствами. Економіка АПК. 2020. № 1. С. $95-100$.

7. Гафіяк А. М. Інноваційні методи використання CRM-систем для підвищення рівня підготовки фахівців 3 інформаційнокомунікаційних технологій. Духовність особистості: методологія, теорія і практика. 2019. Вип. 3. С. 53-61.

8. Черняк О. І. Нечіткий підхід до оцінювання рівня інформаційних ризиків у CRM-системах. Нейронечіткі технології моделювання в економіці. 2016. № 5. С. 199-232.
9. Степанов М. М. Криптографічний захист інформації, що циркулює в інформаційних ресурсах ERPсистем. Зв'язок. 2016. № 2. С. 6063.

10. Катрич Д. В. Захист інформації в ERP-системі підприємства. Адаптивні стеми автоматичного управління. 2017. № 2. C. 17-25.

11. Мищенко А. В. Нечітка модель оцінки ризиків інформаційної безпеки та підтримки рівня захищеності ERP-систем. Телекомунікаційні $\mathrm{ma}$ інформаційні технології. 2020. № 1. C. $142-151$. 


\section{REFERENCES}

1. Bakharyeva, Ya. V. (n.d.). Napryamy rozvytku informatsiynykh system $i$ tekhnolohiy obliku pidpryyemstv maloho ta seredn'oho biznesu $v$ Ukrayini [Directions of development of information systems and technologies of accounting of small and medium business enterprises in Ukraine]. Retrieved from: http://nbuv.gov.ua/UJRN/efek_201 8_11_90. [In Ukrainian].

2. Lahuta, V. V. (2020) Pidvyshchennya yakosti kibernetychnoyi bezpeky $v$ informatsiyno-telekomunikatsiyniy systemi pidpryyemstva [Improving the quality of cyber security in the information and telecommunications system of the enterprise]. Suchasnyy zakhyst informatsiyi, 1, 37-41. [In Ukrainian].

3. Halakhov, Ye. M. (2019) Stratehichni priorytety systemy informatsiynoyi bezpeky pidpryyemstva, shcho zaluchaye frilans-resurs [Strategic priorities of the information security system of the enterprise, which involves a freelance resource]. Suchasnyy zakhyst informatsiyi, 3, 30-35. [In Ukrainian].

4. Medushevskyy, S. (2020) Avtomatyzovani informatsiyni systemy yak elementy systemy upravlinnya yakistyu farmatsevtychnoho pidpryyemstva [Automated information systems as elements of the quality management system of the pharmaceutical enterprise]. Tekhnichni nauky ta tekhnolohiyi, 4, 65-71. [In Ukrainian].
5. Pryshchepa, Ye. A. (2016). Metod rozrakhunku chasu tranzaktsiy $u$ rozpodilenykh kompyuternykh merezhakh pry pobudovi informatsiynykh system pidpryyemstv [Method of calculating transaction time in distributed computer networks in the construction of information systems of enterprises]. Visnyk universytetu "Ukrayina", 1, 175-180. [In Ukrainian]

6. Pavlyk, V. P. (2020). Systematyzatsiya metodiv u informatsiynomu zabezpechenni upravlinnya pidpryyemstvamy [Systematization of methods in information management of enterprises]. Ekonomika APK, 1, 95100. [In Ukrainian].

7. Hafiyak, A. M. (2019). Innovatsiyni metody vykorystannya CRM-system dlya pidvyshchennya rivnya pidhotovky fakhivtsiv z informatsiyno-komunikatsiynykh tekhnolohiy [Innovative methods of using CRM-systems to increase the level of training of specialists in information and communication technologies]. Dukhovnist' osobystosti: metodolohiya, teoriya $i$ praktyka, 3, 53-61. [In Ukrainian].

8. Chernyak, O. I. (2016) Nechitkyy pidkhid do otsinyuvannya rivnya informatsiynykh ryzykiv u CRMsystemakh [Fuzzy approach to assessing the level of information risks in CRM-systems]. Neyronechitki tekhnolohiyi modelyuvannya $v$ ekonomitsi, 5, 199-232. [In Ukrainian].
9. Stepanov, M. M. (2016) Kryptohrafichnyy zakhyst informatsiyi, shcho tsyrkulyuye $v$ informatsiynykh resursakh ERPsystem [Cryptographic protection of information circulating in the information resources of ERPsystems]. Zv'yazok, 2, 60-63. [In Ukrainian]

10. Katrych, D. V. (2017). Zakhyst informatsiyi $v$ ERP-systemi pidpryyemstva [Protection of information in the ERP-system of the enterprise]. Adaptyvni systemy avtomatychnoho upravlinnya, 2, 1725. [In Ukrainian].

11. Myshchenko, A. V. (2020). Nechitka model' otsinky ryzykiv informatsiynoyi bezpeky ta pidtrymky rivnya zakhyshchenosti ERP-system [Fuzzy model for assessing the risks of information security and maintaining the level of security of ERP-systems]. Telekomunikatsiyni ta informatsiyni tekhnolohiyi, 1, 142-151. [In Ukrainian]. 